\title{
'As good as the West': two paradoxes of globalisation and landscape architecture in St. Petersburg
}

Jacky Bowring, Shelley Egoz and Maria Ignatieva / Lincoln University, Canterbury, New Zealand

\begin{abstract}
One of the challenges of contemporary landscape architecture is the globalisation of place. Nowhere is the threat of homogenisation more apparent than in places vulnerable to change, where the potential loss of heritage fabric rings alarm bells. St. Petersburg is one such place, a UNESCO World Heritage site and a city which had existed outside of the excesses of late 2oth-century Westernisation owing to its sequestration inside the Soviet Union. The city is changing in response to exposure to the West, and this could be a cause for concern, a worry that the city will become just another 'placeless' place. However, we argue that this is a superficial reading, and that in looking more deeply into the history and culture of St. Petersburg, a legacy of borrowing from elsewhere is revealed. Moreover, the aspirations for global ideals are not necessarily 'placeless', as we illustrate through the ways in which St. Petersburg has made the landscapes its own through the invention of tradition and a persistent sense of 'the local' which is indelible to change. We use two case studies to explore the dynamics of the global and the local in St. Petersburg: the historic case of the grand palatial grounds of Peterhof, and the modern pedestrianised street of Malaya Sadovaya.
\end{abstract}

Landscape architecture / globalisation / heritage landscapes / placelessness

\section{Introduction}

In June 2007 three of us - Russian-born, Israeli-born and New Zealanderwent to Russia, to the Globalisation and Landscape Architecture (GaLA) conference held at the St. Petersburg State Forest Technical Academy [1]. We are all landscape architects and were very involved in the conference organisation, the theme of which had emerged from a coalescing of observations and ideas about what was happening in all our native countries in terms of the changing landscape. The conference's global focus was reinforced by the broad international spectrum, with participants from Russia, New Zealand, Australia, Canada, USA, South Africa, the United Arab Emirates, Iran, Lebanon, Israel, Turkey, Portugal, China, Korea, Taiwan, Estonia, Lithuania, Austria, Sweden and Italy.

The emblematic view of the effects of globalisation on landscape architecture is often abbreviated to discussions of the homogenising influence of 'placeless' design. This 'McDonalds' brand of landscape design is one of the profession's key concerns, because with the homogenisation and universalisation of landscape comes the loss of one of our key sources of identity as individuals and as cultures: the uniqueness of place. (Figs. 1,2)

However, while the standardising influence of globalisation on the landscape is of great concern, it is only one aspect of a very complex issue. Our visit to St. Petersburg prompted contemplation of the multi-faceted nature of globalisation of the landscape, through what we witnessed in the local landscape, and from a self-awareness of our own place in that world. Two of us were 'outsiders', in a landscape and culture quite alien to us. We were very conscious of the preconceptions we held about the importance of local identity in design, and of the imported perspectives that we carried to the landscapes that we saw. Maria had a unique position in being an 'insider-outsider', having spent all her early life in St. Petersburg, the USSR, with all its restrictions and limitations, but now being very much a global citizen, having lived in the United States and currently being resident in New Zealand. Maria is familiar with the 'inside' world of Russian Socialist society and its vision of Western culture.

Under the Soviet Regime, Russian landscape architecture dealt with public spaces based on modern and constructivist pre-World War II models, and landscape architects had no access to examples of what the profession was pursuing in Western countries. Western design for the private domain was considered to be servicing the 'rich exploiters' and as such 

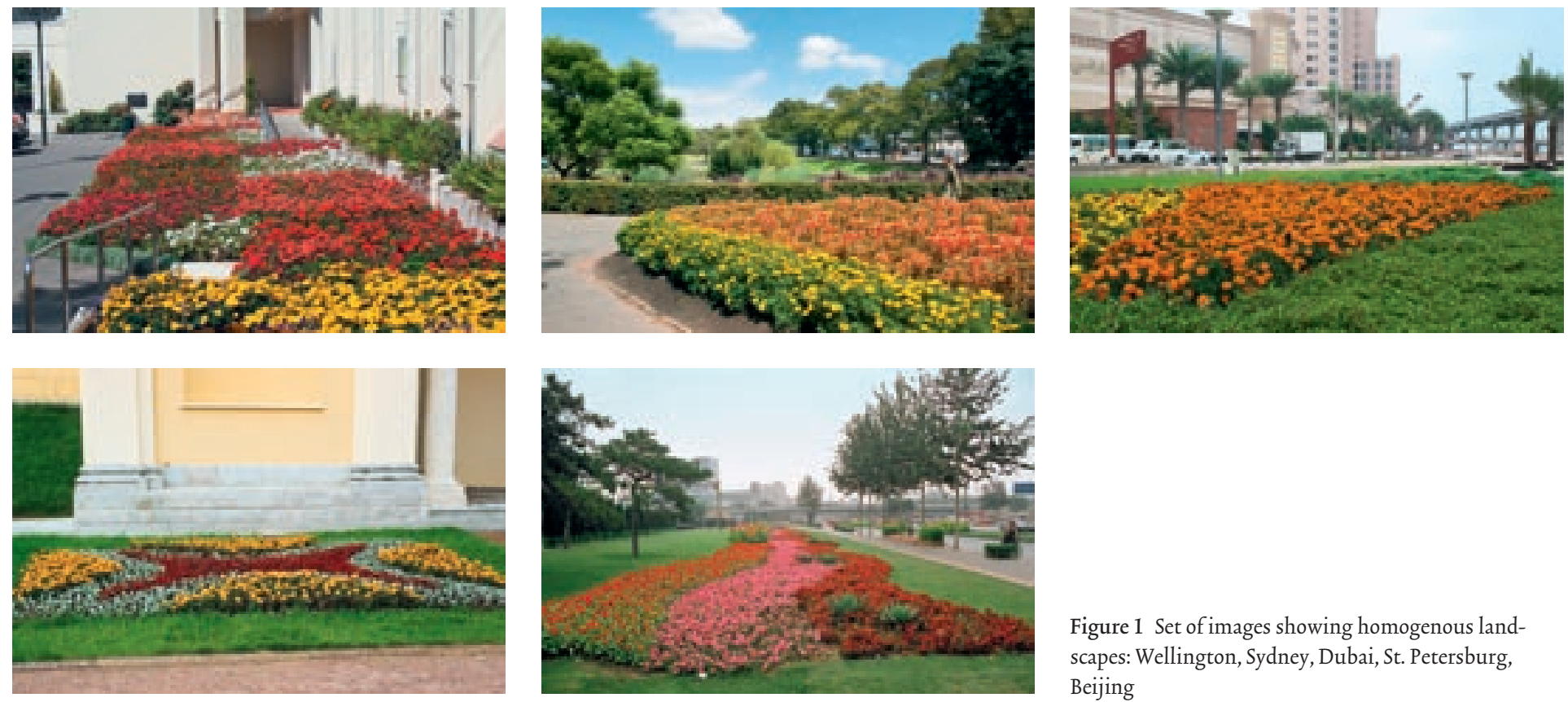

Figure 1 Set of images showing homogenous landscapes: Wellington, Sydney, Dubai, St. Petersburg, Beijing
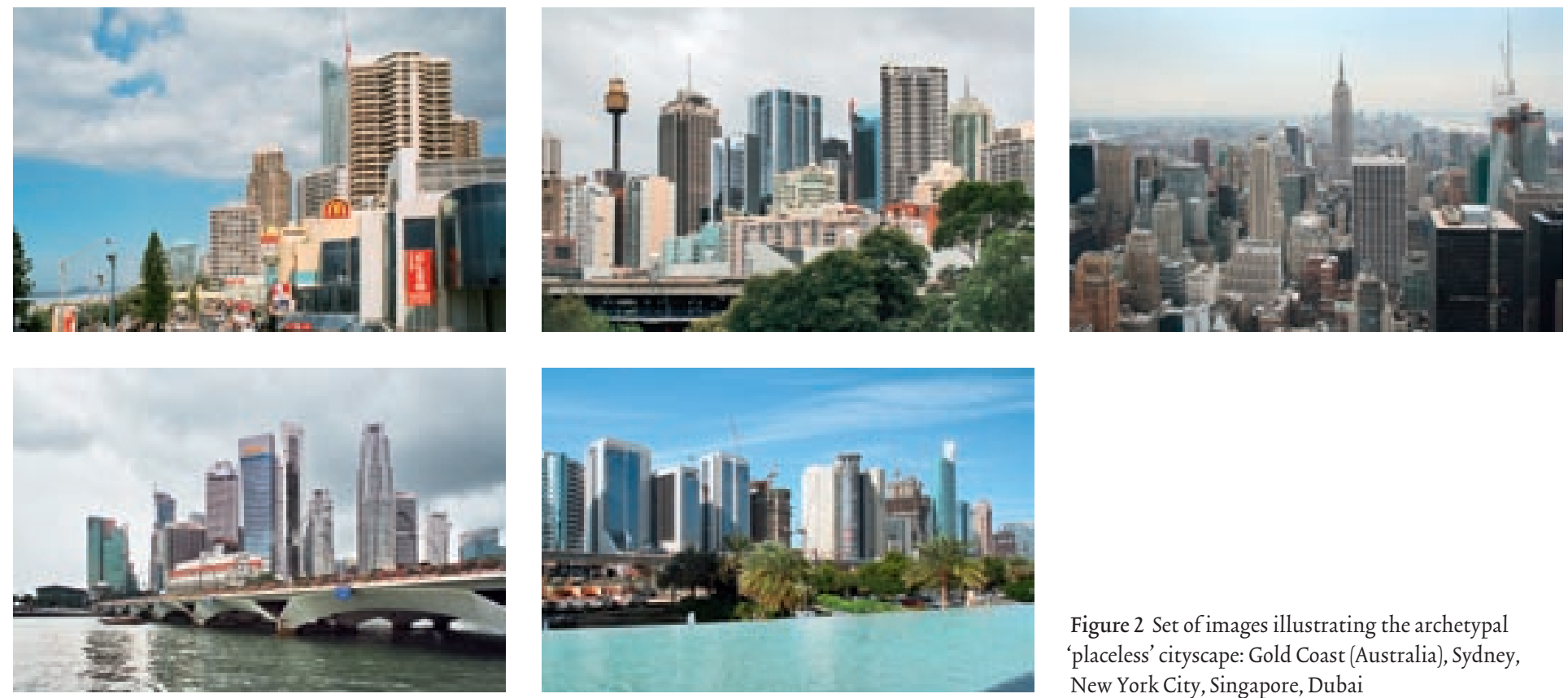

Figure 2 Set of images illustrating the archetypal 'placeless' cityscape: Gold Coast (Australia), Sydney, New York City, Singapore, Dubai

was excluded from professional practice in Russia. At the same time, for Western landscape architecture professionals who might have had some general knowledge of a few famous 18th and 19th Russian Tsars' gardens, most of the Russian landscape architecture heritage was a mystery.

After the collapse of the Soviet Union, Russia opened up for Westerners and Russians were allowed to travel freely to the West. One of the most dramatic changes in terms of landscape architecture was the uncritical endorsement of all Western landscape architecture values by the Russian landscape architecture profession.

This paper addresses some of the questions raised for us about our visit there - aspects that emerged as contradictions and conundrums.
The landscape of St. Petersburg

Asking questions about globalisation in a city such as St. Petersburg emphasises the very complex nature of the issues at hand. The city is three centuries old, boasts some of the most impressive examples of 18 th century European garden design and has shown incredible resilience through war and ongoing political and economic challenges. The airport code on the plane tickets for our destination was LED, an echo of the name Leningrad, St. Petersburg's previous incarnation and a reminder that the seismic changes in Russian society and politics were actually not that long ago.

From its very beginnings St. Petersburg was one of Russia's best examples of attempting to become 'global' - a word that in contemporary debates very quickly becomes conflated with 'Western'. St. Petersburg is 


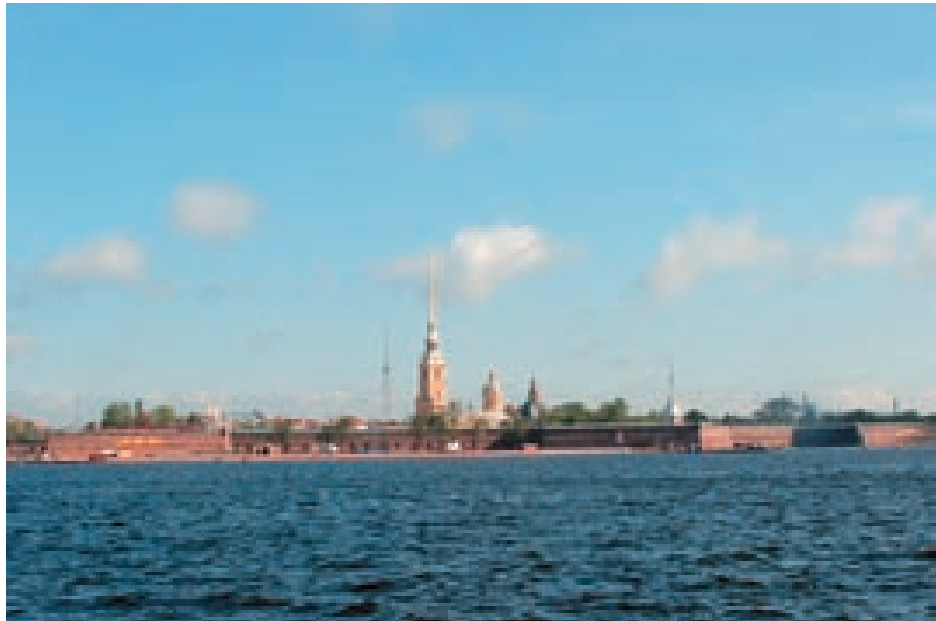

Figure 3 St. Petersburg, 'Venice of the North'
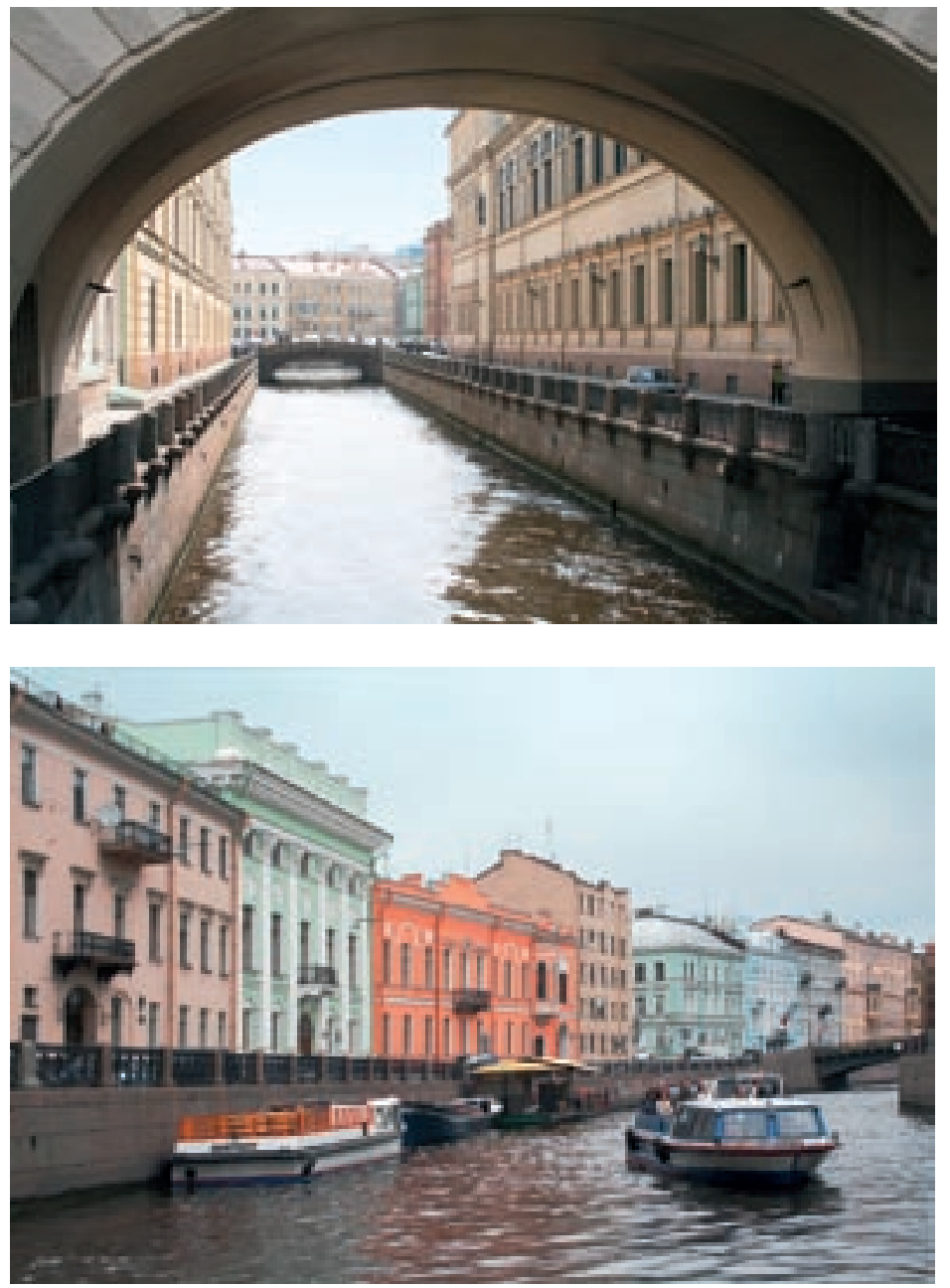

considered the first progressive and civilized Russian urban centre, the first to adopt European secular science, art and architecture (Ageeva 1999). Founded by Tsar Peter the Great in 1703 on the delta of the River Neva, the new capital was conceived as "the window to Europe," a gesture which signalled Russia's aspiration to inclusion within Europe as one of the world's richest and most powerful empires. Peter the Great began implementing unique large-scale experiments to transform the natural landscape [2] and apply some of the most modern principles of European urban planning design, architecture and garden art to the Russian landscape. The low-lying boggy terrain of the Neva delta with its 42 islands, 69 rivers and numerous tributaries became the magnificent European capital known as 'New Amsterdam', the 'Venice of the North' or 'New Rome' (Ignatieva 2005). (Fig. 3)

Western approaches to landscape design were applied on a vast Imperial Russian scale, and many European architects, gardeners and artists were recruited to assist with the design of Imperial palaces, parks and gardens. Baroque principles of urban space organisation were adopted to symbolise the supreme and absolute power of the Russian Tsars. St. Petersburg's urban planning system had spatial integrity, composed of urban spaces such as squares and waterfronts on a heroic scale, a radial and grid street structure, perspective-based axes and a system of striking visual elements at the end of these axes that unified the overall structure. (Fig. 4) The uniquely integrated city, its low skyline allowing the cathedrals to assume pride of place, has its origins in the carefully controlled environment established in the Tsarist regime. This legacy was recognised when the city achieved UNESCO World Heritage status in 1991, as the "Historic Centre of Saint Petersburg and Related Groups of Monuments'.

Peter the Great's introductions were considered highly innovative and progressive for his time. Strict state policies regulated the city's development. Protective mechanisms such as the 'whole street façade' principle dictated the character of constructed buildings to maintain a unified street appearance, along with guidelines limiting the heights of buildings. The Tsar's absolute power and regulatory policies helped create the unique integrity of St. Petersburg's urban landscapes.

Interestingly, the Soviet period (1917-1991) did not affect the historical centre of St. Petersburg, or Leningrad as it was known then. Although it may seem an ideological contradiction, the Soviet empire continued the tradition, protecting the spatial qualities of this unique Russian and European city. Some Orthodox churches were destroyed in St. Petersburg on ideological aesthetic grounds, nonetheless the character of the urban planning structure was not dramatically changed as it was in other cities like Moscow. New urban and landscape compositions in the style of Russian Constructivism, Soviet Classicism, Stalin's 'Empire' style [3] and the Russian version of Modernism appeared in the construction of new districts of Leningrad. 


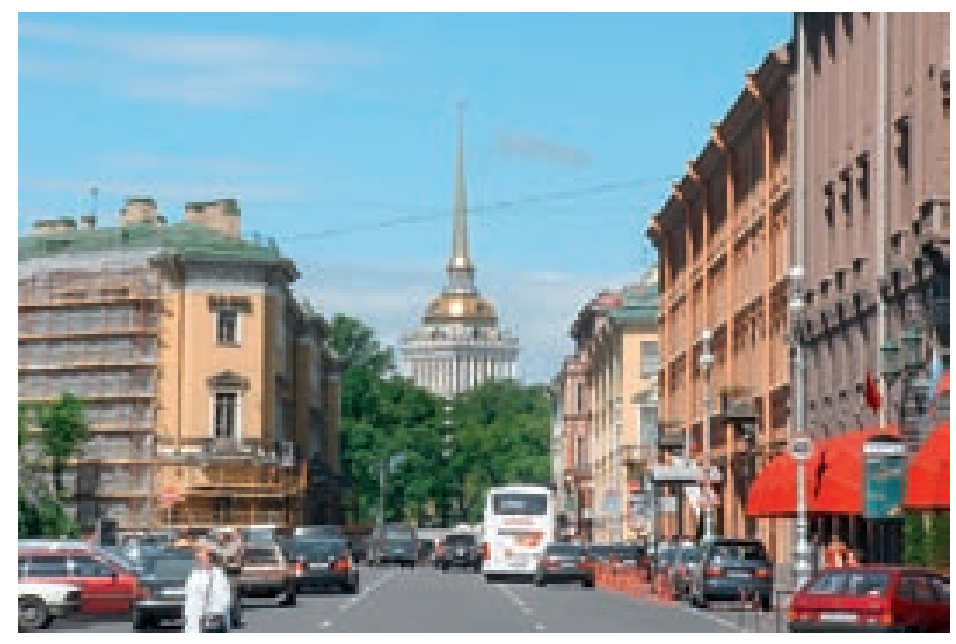

Figure 4 Nevsky Prospect: Axial element from the St Petersburg urban structure

The complex political, economic and social situation of post-Soviet Russia is mirrored in the contemporary Russian landscape architecture market, whether it is actually Western design firms' projects or local designers who are influenced by Western ideas. The West's influence is present even in the names of Russian landscape firms such as Green Paradise, In Nature and Green Park. Western landscape elements dominate everything from plant nurseries to construction materials and technologies such as ceramic brick, lawn and green-roof construction. Anglo-American lifestyles and a Westernised design language underpin the main motto of landscape design today: in its literal translation from Russian, and with the characteristic Russian negative inflection, "Not worse than in the West" or, as a Westerner might express it: "As good as the West", 'The West' for Russia being the USA and Europe (Belaya 2005).

After the collapse of the Soviet Union a period of confusion, corruption and 'wild capitalism' saw landscape architecture abandon all interest in public space design and cater solely for a private garden design market to serve a new class of rich Russians. In the past 6 years, a reasonably stable political state has once again seen Russian landscape architecture returning to engagement with the design of open public spaces. Examples of urban inner yard reconstruction, new public parks in residential micro-districts and designs for pedestrian streets and children's playgrounds have become part of the repertoire of landscape architects. The design of these new open public spaces is mostly inspired by Western examples, in the case of St. Petersburg primarily European, reflecting the geographical proximity and European historical foundations of the city. Recent examples of St. Petersburg pedestrian precinct design, Malaya Sadovaya and Bolschaya Moscowskaya, predominantly display the style of 'routine' modernism, the uncritical formula that is the mainstream, even clichéd, expression of modernist principles. Russian landscape architects, the authors of modern St. Petersburg's urban design, have explained and jus- tified the use of this particular design language. Their argument is that while Western designers have always been part of the global exchange of ideas and styles in landscape architecture, during the Soviet era Russian professionals were deprived of this opportunity. For Russians, globalisation is viewed as the chance to 'catch up' on what was lost from a professional point of view in the years behind the Iron Curtain and to bring their practice in line with that of other countries, so what might be clichéd or 'routine' in the West, is still part of the evolution of design expression in places not yet exposed to this approach to urban space and building. Some Russian landscape architects who have had the opportunity to travel and see different Western examples believe that most of their contemporaries are apprehensive about endorsing Western-style. Those who favour the importation of Western-style landscape architecture dismiss this Russian phenomenon as an "illusion" and a "complex of historicism" (Nefedov 2007), and call for Russian landscape architecture "to be free from this complex."

The well-known 2oth-century St. Petersburg scholar Dmitri Likhachev (1906-1999), a survivor of Soviet prison camps and the Leningrad Siege, battled for many years to protect St. Petersburg from the worst expressions of the Soviet empire's power and to save the unique historical qualities of the "strong and beautiful" city landscape. There is therefore a bitter irony in the situation where, with the advent of 'freedom', the threats to a landscape legacy are graver than ever, and that this threat comes from landscape architecture itself. It is important, however, to raise awareness of the value of an open debate within the context of the freedom permitted by the 'free market' about an appropriate design language in the historical part of St. Petersburg. We therefore present two case studies that exemplify some of these tensions and raise some questions that may enrich such a debate. 

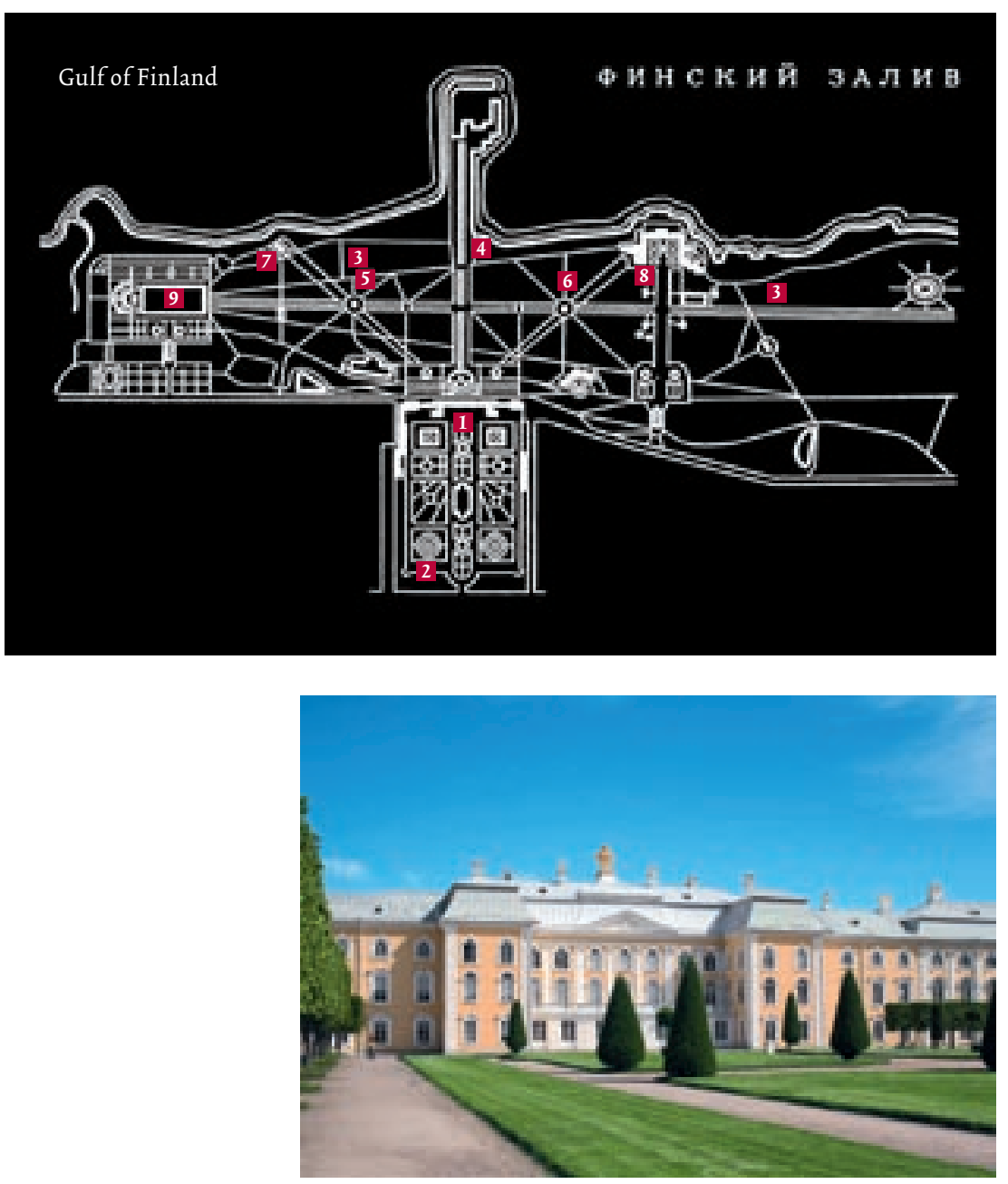

Figure 6 Peterhof Upper Garden
1 The Great Palace

2 The Upper Park

3 The Lower Park

4 The Grand Canal (Samson Canal)

5 Eve Fountain

6 Adam Fountain

7 Hermitage Pavilion

8 Monplaisir Palace

9 Marly Palace
Figure 5

Plan of Peterhof based on an original drawn by Natalia Ilinskaya (1984)

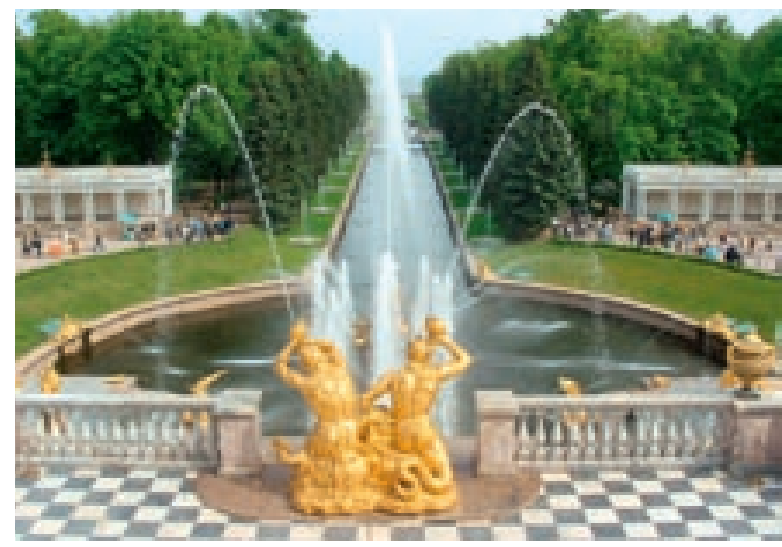

Figure 7 Sea View from Peterhof s Great Palace, looking down the Grand Canal towards the Gulf of Finland
Paradox 1. The global as the local:

Peterhof: Russianisation of French Baroque

The spectacular Tsarist palace-and-park complex of Peterhof, known as the 'Versailles of the North' or the 'Sea King Park', is unique, not only in Russia but also internationally, and has been listed as a UNESCO World Heritage Site. (Figs. 5, 6)

The grandeur of the gardens with its extensive system of remarkable fountains and cascades is a metaphor of Russia's victory in the Northern War (1700-1721), the recovery of the country's Baltic lands from the Swedes, and the importance of the sea as a new access for Russia to Europe. (Fig. 7)

The park glorifies the absolute monarchy and reform activities of Peter the Great in the magnificent nature of its overall composition and also in details such as broderie parterres and the palace architecture, fountain themes and sculptures. (Fig. 8, 9)

The scale of the residence itself is enormous. Peterhof s garden complex was based on a contrast between the modestly scaled and reserved structure of the Upper Garden of 15 hectares, the garden vestibule, and the large Lower Park of 102 hectares with the main attractions, palaces and fountains that stretch along the Gulf of Finland. The Great Palace was built on the highest ground and dominates the composition; it reflects the control of Peter over his country and people. The three cascades and 173 fountains, engineered on innovative hydrological principles such as natural gravity, were a new element in Russian garden art. (Fig. 9) Inclusion of micro-ensembles of small palaces with cascades and fountains such as the Monplaisir, Marly and the Hermitage are typical features of Peterhof s Lower Garden.

During the Second World War Peterhof was completely destroyed, and after the war the park was reconstructed using detailed, scientific restoration methods. Today Peterhof is one of the most popular tourist attractions in St. Petersburg. One of the contradictions of Peterhof, and other gardens that underwent major reconstruction in the post-war period, is that a garden so strongly symbolic of the Tsarist period retained its status under a radically different political regime. The gardens - arguably some of the most potent expressions of Tsarist ideology - were resurrected from the rubble of war to attain their previous glory. Restoration of lost Tsarist parks and gardens sent a strong political message to the rest of the world, that Soviet society valued Russian heritage despite its Tsarist origins. The Socialist justification was that the value lay in the fact that it was also created by “workers' hands".

Added to this contradiction is the curious paradox of Peterhof s 'Russianness'. It is undeniably 'of the place' in its response to its maritime set- 


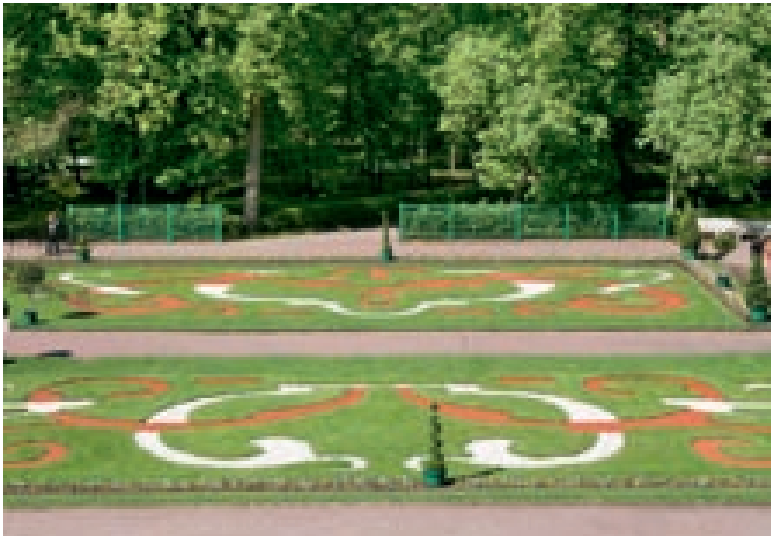

Figure 8 Broderie parterres at Peterhof
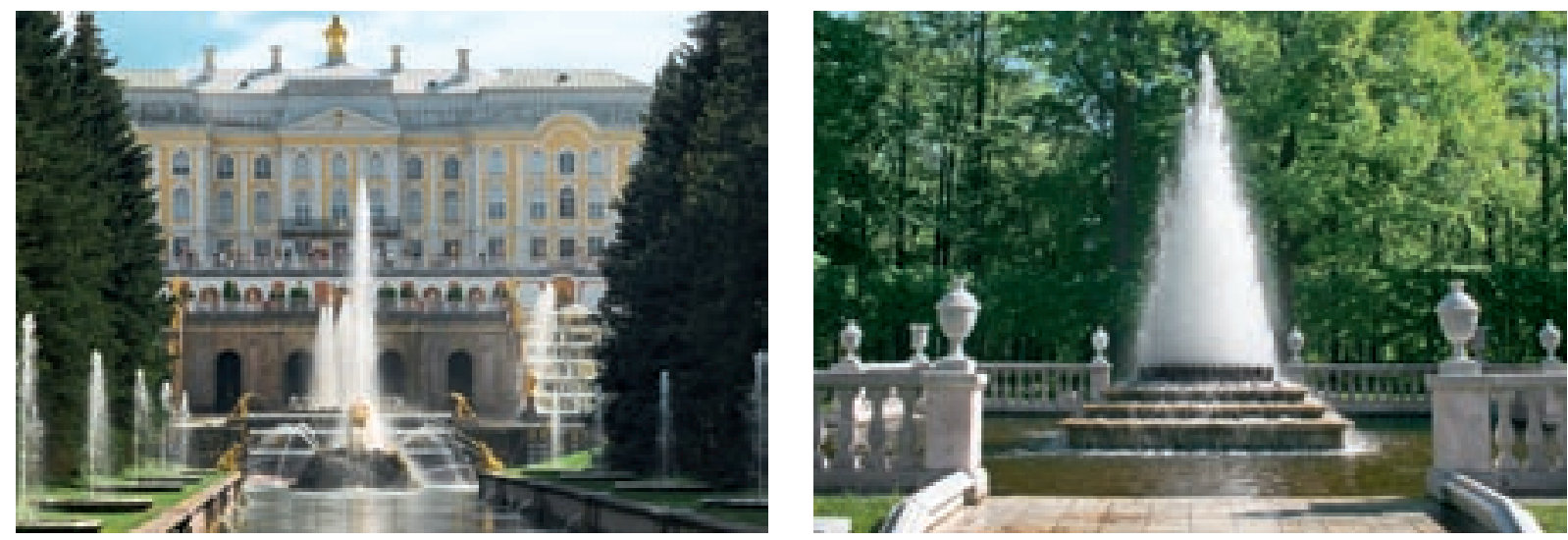

Figure 9 Fountains at Peterhof

ting and in the coherent cultural overlay of built elements as shown in the plan (Fig. 5), the axis to the sea (Fig. 7) and the relationship with the Gulf of Finland shown in Fig. 10. There were very practical dimensions to this setting, as the sea and canal up to the palace were used for transportation under Peter the Great, and this functionality is an emphatic response to place in the same way that all vernacular forms are derived from the provisions of the locality. The parameters of place - topography, vegetation, climate - are immutable aspects of Peterhof and ground the design in its setting. However, this is also a design which wholeheartedly drew upon external sources - essentially the same process that is happening today, of looking to the West for design inspiration. The parallels are strong in terms of the symbolic dimension as, in addition to the sea and canal being functional attributes of the site, they were also part of a re-interpreted design language derived from the gardens of the French Formal style. The axis out to the sea evoked the idea of 'eternity', as the ocean is considered infinite, presided over by Neptune. This echoes the design language that provides the metaphysical armature for the gardens of Le Nôtre, where the underlying aspiration was also to depict ideas of infinity and thereby to allude to God. In the case of Le Nôtre's garden for Louis XIV at Versailles it was the sun god Apollo rather than the sea god that was central to the symbolic repertoire. Versailles has the Apollo Fountain, and Peterhof echoes this with the Neptune Fountain in the Upper Park. As Allen S. Weiss (1995) explained, "By means of the topographic and geographic disposition of the gardens [at Versailles], the sun - as well as the vanishing point at infinity with which the setting sun is homologized - becomes an inte- gral part of the garden's symbolic structure." In both cases the expression of God is through the gesture towards the eternal and infinite - through perspectival direction towards the sun and sky at Versailles, and through the axial trajectory towards the sea at Peterhof.

So, the first conundrum with which we struggled was this spectacular garden with its contradictions: a Tsarist garden reconstructed by the Soviets, and a seemingly 'Russian' garden based on ideas overtly borrowed from the West. Like many Russian contemporary designers who display a 'hunger to catch up' with Western design language, from the beginning of his reign, Peter the Great tried to adopt Western ideas and 'ground' them in Russian soil. The Tsar-innovator strove to import the achievements of European civilisation to the stagnant Russian Boyar society and make Russia better and stronger, but at the same time to exhibit to the rest of the world the power and wealth of the Russian Empire. Peterhof became a hybrid, a 'Global Russia' that stands today as a symbol of the 'local'.

Paradox 2: Globalisation as democratisation:

Malaya Sadovaya pedestrian zone

The second conundrum was that of a very contemporary insertion within the city fabric. On our visit to this example of recent urban design we found it bustling with activity, with passers-by engaging with the various features of the street. Yet these street elements had the sense that they could be anywhere - they didn't seem specific to this place. The granite fountain was like so many that dot urban plazas around the world, with its awkward placement on the street adding to the feeling that it had ar- 

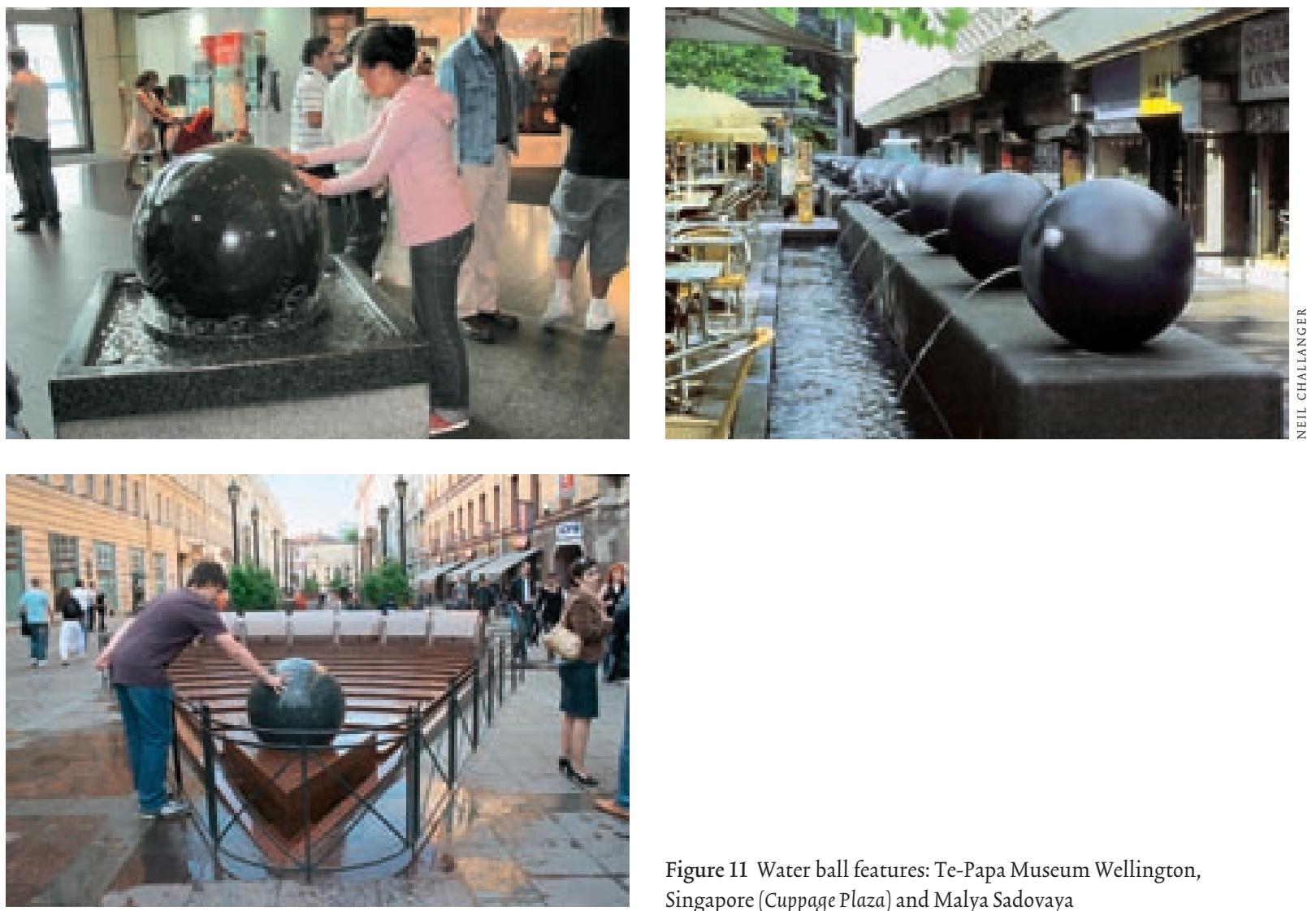

Figure 11 Water ball features: Te-Papa Museum Wellington,

Singapore (Cuppage Plaza) and Malya Sadovaya

rived from elsewhere. (Fig. 11) Other aspects such as small sculptural figures of cats on the roofs, the photographer, the 'kind dog' and marble lions also seemed trivial in relation to the vast and heroic scale of the surrounding city and to the grand traditions of Russian landscape design as expressed at Peterhof (Fig. 14).

Malaya Sadovaya was built in the mid-18th century as a connecting artery between Nevsky Prospect and Italiyanskaya Street (Fig. 12). At just 179 metres it is the shortest street in St. Petersburg, but its location is spatially significant within the city's urban structure. It leads into Nevsky Prospect opposite Catherine II Square with the 19th-century monument to Catherine the Great.

Following Western urban design trends, Malaya Sadovaya was designed by St. Petersburg architects Domracheva and Kharchenko as a pedestrian zone in 1999. The introduction of similar pedestrian zones in Russian cities during the Perestroika and Post-Perestroika eras is related to changes in political structures: the provision of public space is a prominent attribute of urban lifestyle in bourgeois society and as such a symbol of Western democracy. The first pedestrian zones appeared in Moscow, the political and fashion capital of Russia. St. Petersburg, as the cultural capital of Russia, immediately followed this new urban design trend (Fig. 13).

The new design's focal point is a small scale fountain-clock - a granite ball floating on the water. (Figs.11, 14). The street is colourfully paved, has an underground heating system and is decorated with several sculptures of people and animals. Implementation of this project provoked controversy among the citizens. A range of contrasting responses were voiced, some expressing admiration and others criticising the architectural style of the street, a style felt to lack integrity and seen as a foreign intrusion into the city's legacy (Zhelnina 2006).

Nonetheless, a study by Russian researchers based on a North American methodology of analysis of urban public spaces examined the behaviour and interaction of visitors in this street as well as the broader spectrum of a public culture. Their findings showed that this pedestrian precinct is the only successful example of a new type of urban public space in St. Petersburg (Zhelnina 2006). Malaya Sadovaya can be included among several examples of urban public space transformation in post-Socialist Central and Eastern European countries attempting to include post-Soviet urban culture in the global system of Capitalism (Andrusz et al 1996; Czepczynski). While the last decade has seen a growth in literature on postSocialist public spaces in Central and Eastern European countries, Russia has only recently introduced the term 'urban public space' (gorodskoe publichnoe prostranstvo) (Zhelnina 2006). This term was introduced in the $1990 \mathrm{~s}$ (the time of Perestroika and before the renovation of Malaya Sadovaya) directly from Western academic literature and was used mostly among researchers. At the moment the concept of new public spaces is still ideologically fairly immature. The City Administration does not use this term, preferring 'open spaces', which is too general and does not specify the new concept (A. Zhelnina, personal communication 26 November 2008).

The reasons for such a time-lag compared to the other 'Socialist brethren' are the different historical and political contexts, the vastness of Russia, and even the climate, whose very harsh winters limit the speed of change. Former Soviet satellites began their transformation to the Capi- 

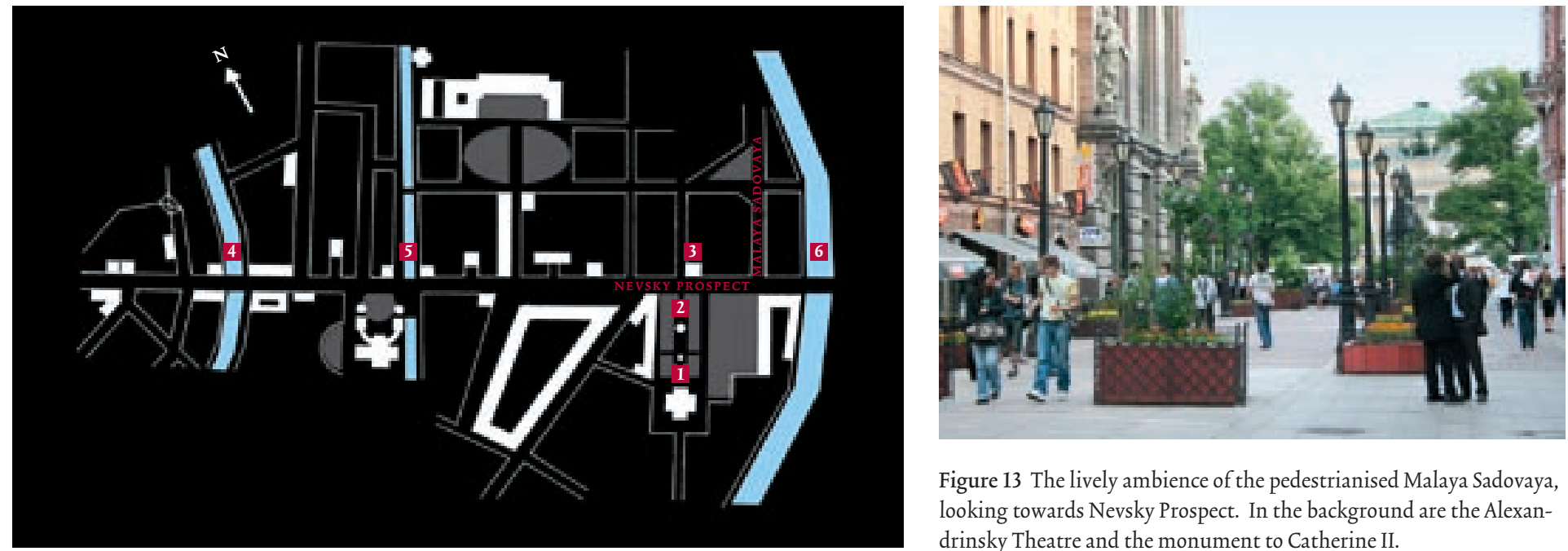

Figure 13 The lively ambience of the pedestrianised Malaya Sadovaya, looking towards Nevsky Prospect. In the background are the Alexandrinsky Theatre and the monument to Catherine II.

Figure 12 Central St. Petersburg showing the location of Malaya Sodovaya north of Nevsky Prospect, on the axis of the Alexandrinsky Theatre and the monument to Catherine II
1 Alexandrinsky Theatre

2 Monument to Catherine II

3 Theatre of Comedy and the Yeliseyevs' Food Store

4 Moyka River

5 Griboyedov Canal

6 Fontanka River talist system much earlier and had closer contacts with Western countries compared to Russia. Moreover, St. Petersburg's situation is even more distinctive than the other post-Socialist nations due to its designated Heritage status under UNESCO, a status that imposes a set of very specific rules and codes. It is important, therefore, to recognise the limitations of ideas about successful urban form, and to beware of extrapolating either the situation of the neighbouring context of Central and Eastern Europe or the broader 'norms' of urban design too far, as to do so can obscure the cultural and physical drivers unique to this setting.

The street has now become one of the best-frequented outdoor public spaces in the city and the only St. Petersburg street that is heated in winter; it has also acquired a special folk cultural and social meaning and become extremely popular with local people. Children and adults are fascinated by the ball of the Clock Fountain and often interact with the water feature. The sculpture of the Photographer with the Dog is the most popular place for taking photos. The mythical cultural dimensions of the street are embodied in the iron sculpture of the 'kind dog' called 'Gavrusha' that contains a box for leaving written wishes, as well as in the good luck ritual where children try to throw coins to the cat sculpture, 'Elisei', high up on a ledge (Fig. 14).

Malaya Sadovaya is also a successful example of transforming street space for a new consumerist urban culture. Its many cafés and shops are always very busy. A street culture of musicians and actors stimulates an atmosphere of urban democracy. The success of Malaya Sadovaya can be contrasted with other new pedestrian streets (e.g., Malaya Konnuschennaya) and recently renovated urban public spaces / inner yards (e.g., Dvori Kapella) which are empty most of time, as noted by sociologist A. Zhelnina, the leading researcher of urban public spaces in St. Petersburg and member of the Centre for Research of Germany and Europe (St. Petersburg State University). (Zhelnina 2006 plus personal communication with A. Zhelnina on 26 November, 2008).
The public response to Malaya Sadovaya prompts thoughts on what constitutes 'the local'. As landscape architecture educators we often encourage students to pursue integrity in design by drawing their inspiration and narratives from the locality and character of the site. The Malaya Sadovaya example shows how a design that, at first glance, we felt to be a foreign transplant, out of place and awkward, was endorsed by the users and became local. Locality and pride of place are perhaps constructed, accumulating meaning through people's interaction with the landscape. As Czepczynski notes in relation to the shifts in the 'emancipated landscapes' of post-socialist European countries, "The old and new semantic rulers transform the old icons via media, law and money, but despite their intentions and ambitions, the meaning of cultural landscape is always verified by the everyday users" (Czepczynski).

\section{Conclusion and discussion}

Looking outward for design inspiration is nothing new in St. Petersburg. Just like the current slogan 'As good as the West', the creator of St. Petersburg, Peter the Great, aspired to Europeanism and used the phrase "As good as the French King has" (Dubyag 1963). For Peter the Great, the landscape of St. Petersburg was a symbol of Pride of Place and a tangible expression of power. For contemporary designers, the enthusiastic endorsement of Western examples can be explained by a sense of deprivation due to their isolation during the years of Soviet rule. The tensions in St. Petersburg between market forces, endorsement of Western values and a wish to retain heritage landscapes is reflected in the current debate in the landscape architecture profession. This debate is of great significance, as landscapes in particular are dynamic entities and heritage conservation always holds more questions than answers.

Heritage and identity are contingent on many factors, and the complexities of cultural exchange make the interpretation of such places challenging. For landscape architecture, these issues are further complicated by 

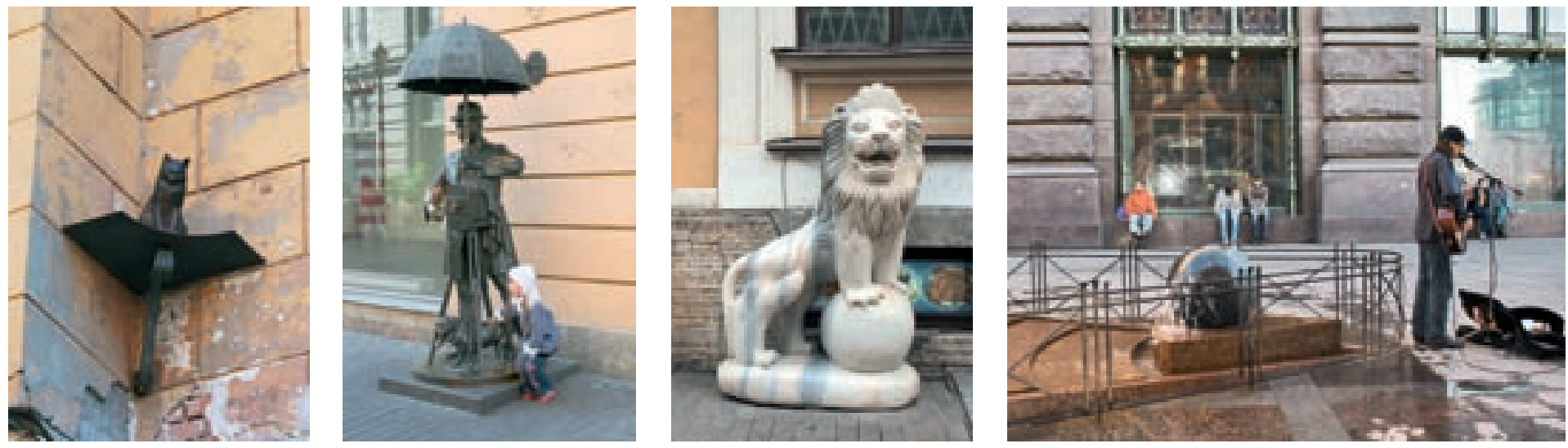

Figure 14 Scenes from Malaya Sadovaya - Elisei the Cat, the Photographer and his Bulldog, the Marble Lion, the Clock Fountain

the superimposition of many versions of landscape identity, palimpsests of both grand ideas and gradual changes. St. Petersburg's present landscape is a demonstration of just how difficult the issues of landscape heritage are, and how easy it can be to overlook the content of landscapes and underestimate the ways in which meaning is inherent to place. Even in the face of rampant globalisation there are subtle nuances in 'the local' that provide inflections of place and culture.

At both Peterhof and Malaya Sadovaya, something introduced from the outside was transformed to become typically Russian. At Peterhof it was the grand vistas and cascades of the French legacy, developed with a distinctly Russian inflection and grounded on the shores of the Gulf of Finland. In the smaller-scale landscape of the street, the localising of generic elements was achieved in part through the particularly Russian trait of imbuing objects with superstitious properties. The fountain was ordained with special properties by citizens, along with the elevation of the statues of the photographer and cats, as important touchstones of the city. Rituals of putting a wish in Gavrusha's special box, or throwing coins to Elisei for good luck, are recent inventions, yet are already naturalised within the city's history. Through these processes of creating particularity and embedding it as 'local', the newly designed Malaya Sadovaya is now a tourist attraction, included in guided tours, and seen as the "official image of the most European of cities in Russia" (Zhelnina 2006).

This adoption and naturalisation of rituals is an example of what Hobsbawm and Ranger (1983) term the "invention of tradition", where a constructed mythology is received unquestioningly as part of identity. As a form of collective memory, invented traditions exemplify the processes described by sociologist Maurice Halbwachs of the forming and reforming of ideas on the past, and the ways in which such memories are shaped and appropriated (Halbwachs 1992). In his exploration of the history of ritualised practice and behaviours Eric Hobsbawm described how "invented tradition is taken to mean a set of practices, normally governed by overtly or tacitly accepted rules and of a ritual or symbolic nature, which seek to inculcate certain values and norms of behaviour by repetition, which automatically implies a continuity with the past." (Hobsbawm 1983:1). Connection to the past is one of the most effective ways to evoke a sense of 'the local', associ- ated with conventions of ways of building, accumulated folklore and ideas of lineage. The rituals of Malaya Sadovaya make connections to 'the local' through a sense of community solidarity and invented legacy. This reflects the particularly Russian tradition of associating superstitions with objects and places, a trait which is even more pronounced in St. Petersburg, evident in the extensive mythology associated with the city. The creation of superstition and mythology is enlisted in the modern-day process, however unwitting, of 'inventing' a sense of 'the local'.

Explicitly, or unconsciously, the users of the street have customised global landscape architecture through subtle details and inflections of behaviour. The dog, the cat, the lion, the photographer, and the ball have become a recognisable constellation within St. Petersburg, and Malaya Sadovaya operates as an armature for what Anderson (1983) calls an "imagined community”, and gathering up Nora's sense of 'imagined continuity' (2001: VIII) through an aspiration for connection to the past. Although such a prospect - of inventing the heritage of place - might seem far-fetched, Svetlana Boym points out that the construction of urban myths is part of St. Petersburg tradition. Boym, a native of St. Petersburg, describes how, "Since Pushkin's (The Bronze Horseman), the 'Petersburg Tale' has mixed realistic and fantastic elements, questioned authority and flirted with madness." (Boym 2001:370)

The 'empty' nature of the symbols on Malaya Sadovaya have allowed them to become vessels for the layers of meaning and superstition now associated with them. They move from avatars within a global world of anonymity to specific figures within the city fabric, with narratives of their own. The 'placeless' landscapes that concern the profession of landscape architecture might therefore be more fruitfully viewed as containers that are available for the collection of local material. At the grander scale of Peterhof the borrowed elements from Europe are adopted and adapted to local conditions, and anointed as symbolic of place through the process of Russification. The landscape architecture profession's concern for the loss of local identity through globalisation is focused on form, but designed landscapes, once built, take on a life of their own. Perhaps the elements that to an unfamiliar eye seem generic and an expression of placelessness such as those illustrated in Figures 1,2 and 11 may have more to them than initially meets the eye. 
The localisation of Peterhof and Malaya Sadovaya reflect different influences. Peterhof expressed the insistence on place, in terms of topography and climate, and the indelible mark of Russian Tsarist culture honed the imported Western styles and symbols with an emphatically Russian flavour. At Malaya Sadovaya, Russian culture again made its mark, but the influence of global commerce is also at work. The construction of heritage, the invention of tradition, is not solely for the sake of national or city identity - it is also one of the marketable commodities in contemporary tourism. Malaya Sadovaya's popularity as a destination within the city is testament to this successful creation, becoming a charming, distinctive attraction where the 'local' is one of the primary enticements to the global flow of tourists.

These landscapes epitomise the nuances that might be lost in a superficial reading, and through our visit to St. Petersburg we had a unique opportunity to bring together three perspectives on place. Our combined critique of the landscapes of Peterhof and Malaya Sadovaya brought together both an intimate knowledge of local culture and a more globalised professional view which encompasses a collective sense of aesthetics and recognises both the semiotic and discursive attributes of design (Czepczynski). The three of us exchanged a variety of insights and alternative perceptions of the landscapes we encountered, ranging from the foreigner's outsider stance to the insider's intimate and detailed knowledge of place through language and networks. The outsider perspective brings a defamiliarising dimension to the insider's view, discerning aspects which may be so taken-for-granted in a local context as to go unnoticed. Through such dialogues the more subtle nuances of place identity can be discerned, as in the examples of Peterhof and Malaya Sadovaya - two paradoxes of the globalisation of landscape architecture. They are not attempting to resist the West but to embrace it, consciously or subconsciously creating a new 'local', alive with the conundrums which provide a richness and depth to the connections between landscape, design and identity.
Notes

1 The idea to host a conference in Russia was initiated by Maria Ignatieva, a Russian expatriate now resident in New Zealand and her former colleague at the St. Petersburg Forest Technical Academy, Irina Melnichuk. The conference was a joint effort by both Lincoln University, where another colleague, Glenn Stewart, was also involved in the convening, and the St. Petersburg State Forest Technical Academy.

2 The natural landscape of St. Petersburg underpinned the major flooding events due to the city's location on the delta of the River Neva and the hydrology of the Gulf of Finland and the River Neva.

3 Stalin's Imperial style was dominant in Soviet architecture during his rule (1933-1955). The main characteristics of this style are the use of elements of late Classicism, Imperial style and Baroque combined with Soviet symbols of the proletariat culture such as the five-pointed star or hammer and sickle used in the decorative details.

\section{References}

Ageeva, O. G. 1999. Petersburg in Russian social consciousness in the early 18th century. St. Petersburg: Russko-Baltiiski informatsionni Tsentr BLITs. "Velichaishii I slavneishii bolee vsekh gradov v svete” - Grad sviatogo Petra. Peterburg v russkom obshchestvennom soznanii nachala XVIII veka. Peterburg. Sankt-Peterburg, Russko-Baltiiski Informatsionni Tsentr BLIT,s (in Russian)

Anderson, B. 1983. Imagined Communities: Reflections on the Origins and Spread of Nationalism. London: Verso

Andrusz, G., Harloe, M., and Szelenyi, I. 1996. Cities after Socialism: Urban and Regional Change and Conflict in Post-Socialist Societies. Oxford: Blackwell

Belaya, G. 2005. Notes to the young "beholder" of art. Zhametki k portretu molodogo "sozertsatelyu" iskusstva. www.websher.net/yale/rl/cultureintranslation/colloquim/ Belaya-Rus-L-02-27-05.html (in Russian)
Boym, S. 2001. The Future of Nostalgia. New York: Basic Books

Czepczynski, M. 'Emancipated Landscapes of Post-socialist Europe: Old and New Icons and their Representations'. Unpublished Paper. Economic Geography Department, University of Gdansk, Poland.

Dubyago, T. 1963. Russian Regular Gardens and Parks. Leningrad: Stroiisdat. Russkie regulyarnie sadi i parki. Leningrad: Stroiisdat. (in Russian)

Halbwachs, M. 1992. On Collective Memory. Trans. and ed. Lewis Coser. Chicago: University of Chicago Press. (First published 1941).

Hobsbawm, E. and Ranger, T. (eds.) 1983. The Invention of Tradition. Cambridge: Cambridge University Press

Ignatieva, M. 2005. Case Study: Heritage Landscapes in St. Petersburg, Russia: Past and Present. Proceedings of NZILA "Looking forward to HERITAGE LANDSCAPES" 2005 Conference. New Zealand Institute of Landscape Architects Conference Dunedin, 28-30 April 2005: 337-347

Nefedov, V. 2007. Reconstruction of urban environment: landscape aspect of the problem. Landscape Architecture. Design. 3:63-68. Reconstruktsiya gorodskoi sredi: landschaftni aspect problem. Landschaftnaya Architectura. Disain. (in Russian)

Nora, P. 2001. Rethinking France: Les Lieux de Mémoire. Chicago: University of Chicago Press

Weiss, Allen S. 1995. Mirrors of Infinity: The French Formal Garden and 17th-century Metaphysics. (originally published 1992 as Miroirs de l'infini: Le jardin à la française et la métaphysique au XVIIe siècle). New York: Princeton Architectural Press

Zhelnina, A. 2006. Malaya Sadovaya Street in St.Petersburg: experience of public space development. Communitas, no.1. 53-71. Malaya Sadovaya Ulitsa v Sankt Peterburge: opit stanovleniya publichnogo prostranstva. Soobshchestvo, no.1 (in Russian)
Biographical Notes

The three authors all teach in the School of Landscape Architecture at Lincoln University, New Zealand.

Dr Maria Ignatieva is originally from St. Petersburg and has lived and taught in Russia, the USA (State University of New York at Syracuse) and New Zealand.

Dr Shelley Egoz is Israeli-born, and came to New Zealand via a period of study and teaching in the USA (University of Oregon).

Dr Jacky Bowring is a New Zealander, and worked in London before returning to Lincoln University.

The authors have shared research interests in the history of landscape architecture, and a concern for the theory and practice of contemporary landscape architecture, as reflected in Dr Ignatieva's work in progress on Gardens of the Old and New World: The Journey of a Landscape Architect ("St. Petersburg Art"), Dr Egoz's 2008 workshop on The Right to Landscape: Contesting Landscape and Human Rights in collaboration with the Cambridge Centre for Landscape and People (CCLP), and Dr Bowring's recently published book A Field Guide to Melancholy.

Contact

Jacky Bowring

Shelley Egoz

Maria Ignatieva

School of Landscape Architecture

Faculty of Environment, Society and Design

PO Box 84

Lincoln University

Canterbury

New Zealand

Tel: $00643325-3804$

bowringj@lincoln.ac.nz

egozs@lincoln.ac.nz

ignatiem@lincoln.ac.nz 